Egyptian Journal of Archaeological and Restoration Studies
An international peer-reviewed journal published bi-annually
www.ejars.sohag-univ.edu.eg

Original article

\title{
OLD KINGDOM DOOR LINTEL OF ISI AT THE EGYPTIAN MUSEUM
}

Ahmed, B.

Archaeology dept., Faculty of Arts, Ain Shams Univ., Cairo, Egypt

E-mail address: bassemyossef65@gmail.com

\begin{tabular}{|c|c|}
\hline Article info. & EJARS - Vol. 10 (1) - June 2020: 23-27 \\
\hline Article history: & Abstract: \\
\hline Received: $13 / 4 / 2019$ & This rectangular limestone door lintel of Isi is currently housed in \\
\hline $\begin{array}{l}\text { Accepted: } 15 / 10 / 2019 \\
\text { Doi: } 10.21608 / \text { ejars. } 2020.98958\end{array}$ & $\begin{array}{l}\text { Cairo Museum (under Temporary Register No. 6-12-24-8). It } \\
\text { belongs to the end of the } 5^{\text {th }} \text { dynasty and the beginning of } 6^{\text {th }} \\
\text { dynasty of the old kingdom. Although it bears no royal name, it }\end{array}$ \\
\hline Keywords: & has the style of the inscriptions that existed at the end of the old \\
\hline Rectangular & kingdom. This tomb lays in the northern part of the cemetery of \\
\hline Limestone & Deir El-Gebrawi at Assiut, which belongs to the end of $5^{\text {th }}$ dynasty \\
\hline Cairo Museum & $\begin{array}{l}\text { and the beginning of the } 6^{\text {th }} \text { dynasty while the southern belongs to } \\
\text { the reign of PPi the } 2^{\text {nd }} \text { from the } 6^{\text {th }} \text { dynasty. }\end{array}$ \\
\hline & \\
\hline
\end{tabular}

\section{Introduction}

This paper deals with an rectangular painted limestone door lintel of Isi [1] currently housed in Cairo Museum (under Temporary Register No. 6-12-24-8), from his tomb No. (72) at Deir El- Gebrawi at Assiut [2] in Upper Egypt.This tomb belongs to the end of the $5^{\text {th }}$ dynasty and the beginning of the $6^{\text {th }}$ dynasty of the old kingdom. Moreover, There is another smaller tomb No. (46) [3] at the same place that has the same name of its owner, Isi maybe one of the sons or relatives of the owner of the tomb No. (72). They both have asurname $R^{\mathrm{e}} \mathrm{hm}$, and they have also the same titles espicialy hry-tp $3 \underline{d} w-f$ [4], but the tomb No. (72) was the only painted tomb of them. In addition, the figure of Isi at this tomb has been represented with a smallblack pointed beard [1] like his representation at the linte reviwed here. There is a mastaba at Tell Edfu between EL-Kab and Aswan [5], its owner also called Isi, and he belongs to the same era (the beginning of the $6^{\text {th }}$ dynasty). In addition, he has similar titles like the owners of the Deir El-Gebrawi tombs. On the other hand, this mastaba was built from mud brick and limestone inscribed slabs without any remains of colors.

\section{Description}

This rectangular limestone door lintel of Isi, fig. (1) is currently housed in Cairo Museum (under Temporary Register No. 6-12-24-8). It's measerus $48 \mathrm{~cm} \times 110 \mathrm{~cm}$ andit contains dameges in several parts. On the right side, it lost some words and letters signs of the $1^{\text {st }}, 2^{\text {nd }}$ lines and the $1^{\text {st }}$ letter of $3^{\text {rd }}$ line of the text, while in the middle, it lostsome words and letters of the $1^{\text {st }}$ and $2^{\text {nd }}$ lines and on the left side, there is a damege in the upper left corner and it lost the most representation of Isi wife together with her name. Moreover, we can complete the text by comparing it with the parallel texts at the same cemetry or with other texts that belong to the same era. [6]. The text contains sevensunken hieroglyphshorizontal lines and one vertical line before Isi representation that contains his titles and his 
name. In addition, there was another vertical line above his wiferepresentation that contains her title and her name, but the latter was lost. Moreover,there are remains of colores on the text such as black, red and white. Furthermore, the white color had covered the entire text, then the red and black colors were added. On the left side, Isi stands and behind him in a smaller shape, his wife who lost most of her shape except her legs stands. Isi is represented in a formal shape, most of his leges and part of his right arm are damaged. In addition, he wears a black wavy wig showing his ears.
Moreover, he has a black pointed little beard and puts a five-layers beads collar with details around his neck. Furthermore, he wears a short triangular skirtwithcrossed lines as well as he is leaning ona long staff by his lefthand that contains a bracelet and holds a black colored kherep scepter in his right hand.The representation of the whole Isi body is colored in red and his wife wears a tight dress. In addition, as of her feet, the color of her body seems dark yellow. The feet ofboth Isi and his wif are bared.
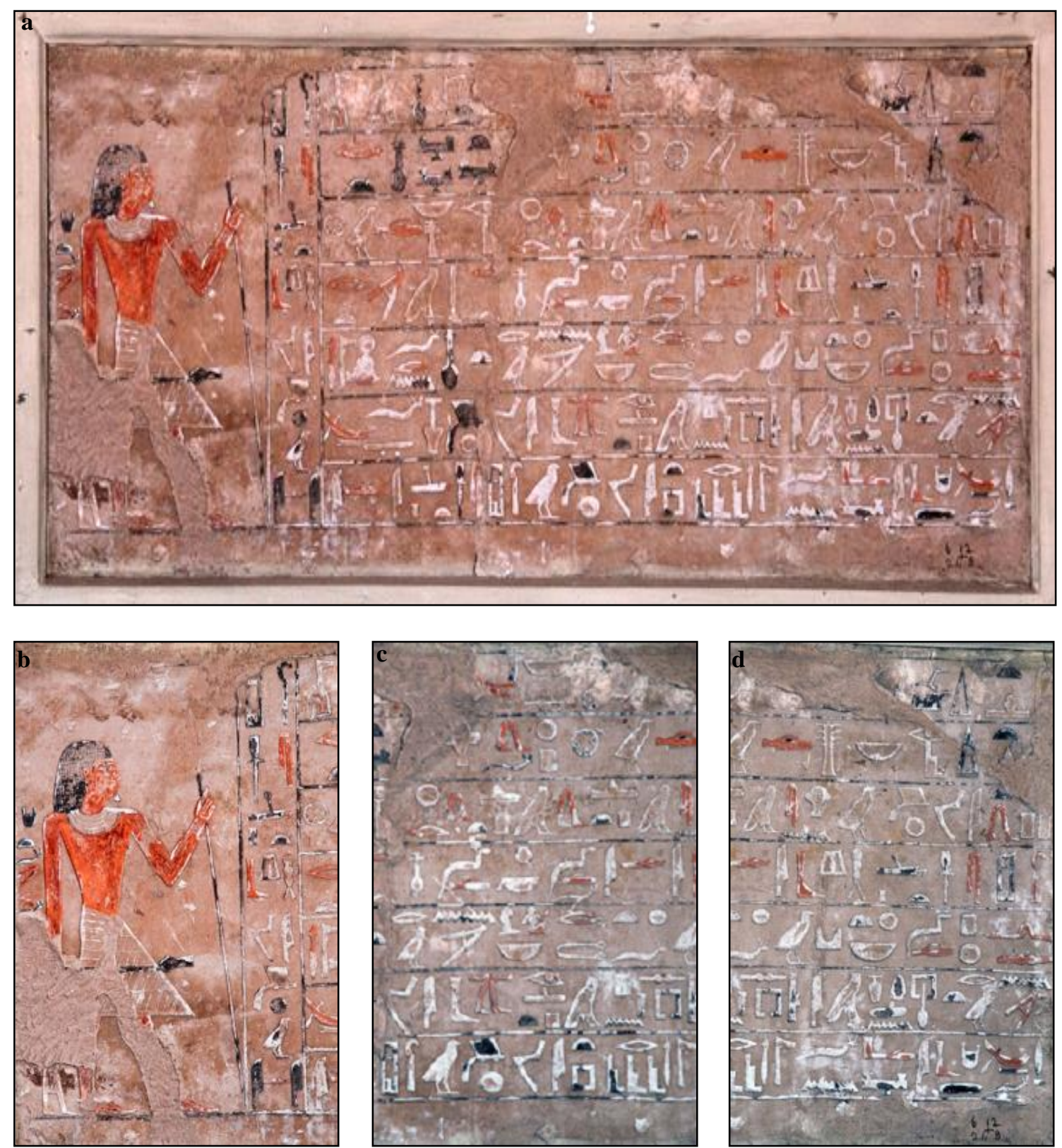

Figure (1) Shows a. limestone door lintel of Isi, $\underline{\mathbf{b}} . \underline{\mathbf{c}} . \mathbf{\&} \underline{\mathbf{d}}$. details of door lintel (Cairo Museum 6-12-24-8) 


\section{Text}

The door lintel of Isi, fig. (2) contains two vertical lines, one in front of Isi have the titles of the deceased. The other behind him have the name of his wife. In addition, cotains the formula of Htp di nisw, the titles of the deceased and the negative confession in which he discharges himself before the Gods court.

there are seven horizontal hieroglyphs lines

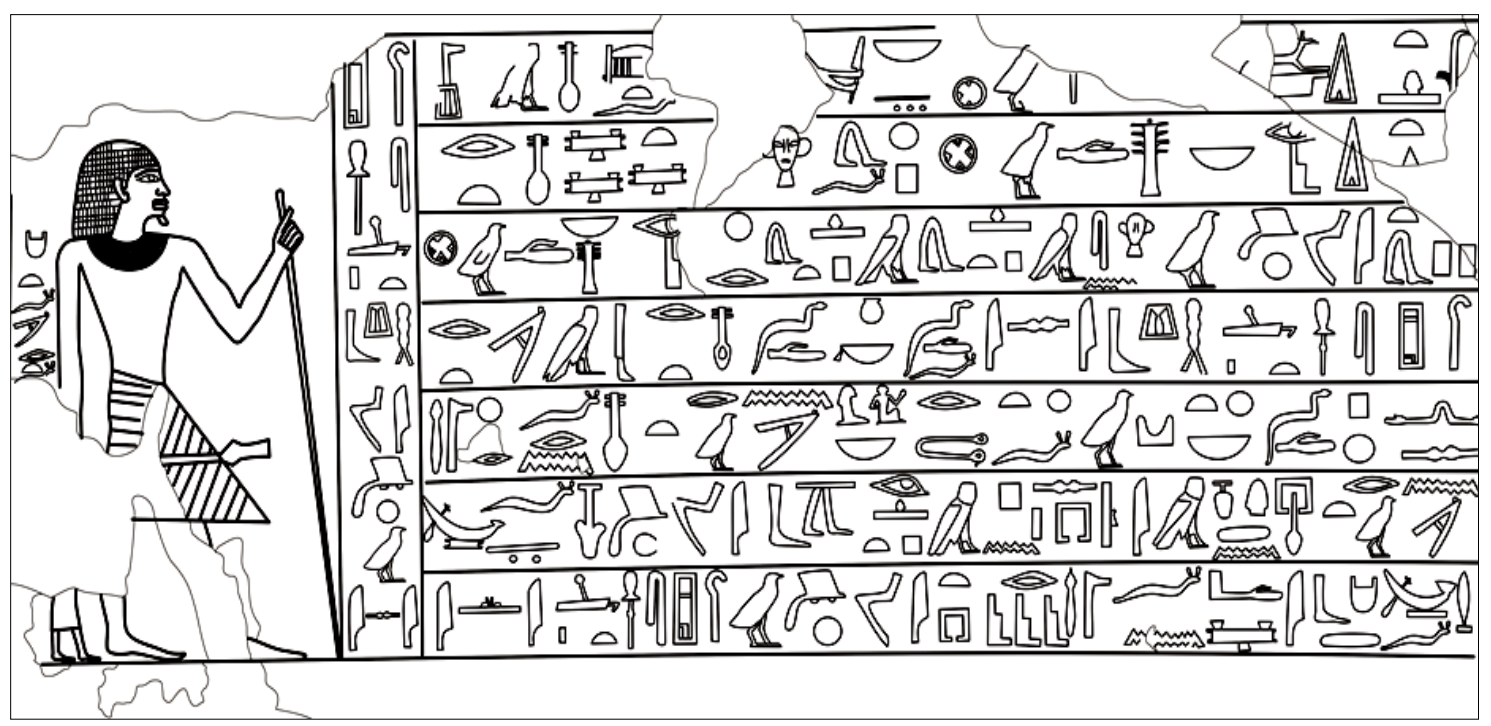

Figure (2) Shows drawing the hieroglyphic writing of door lintel

\subsection{Vertical line before Isi}

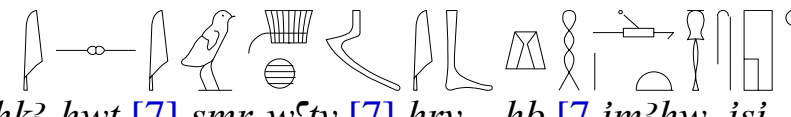

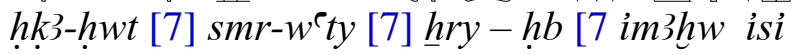

The Estate-manager, sole companion and lector priest, the revered Isi.

\subsection{Vertical line behind Isi}

\subsection{III-Horizontal lines}

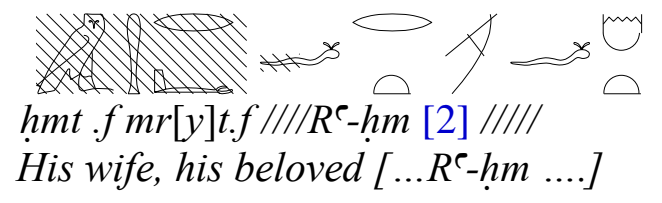

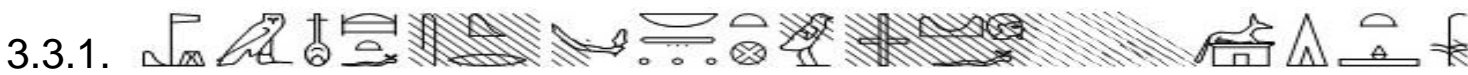 htp -di -nswt [ //I////-[2] (n) Inpw[ tp $\underline{d} w$.f imy]-wt [8] nb t3[ $\underline{d} s r$ [9] Krs].ti.f $n f r(w) m \underline{h} r(t)-n \underline{t} r$

An offering which the king gives; IIIIIII to Anubis- who-dwells upon his mountain, whoinhabits the embalming-place, lord of the sacred land-gives; when he (=the deceased) is buried in te Necropolis.

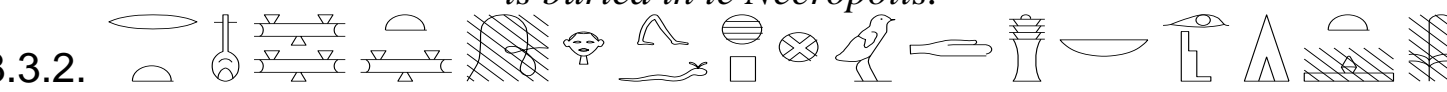

\section{[htp]-di-[nsw]t Wsir nb $\underline{d} d w$ hp.f hr [w3]wt [9] $n f r(w) t$}

An offering which the king, and Osiris - lord of Busiris - give, so that he (=the deceased) may travel on the good roads.

3.3.3.

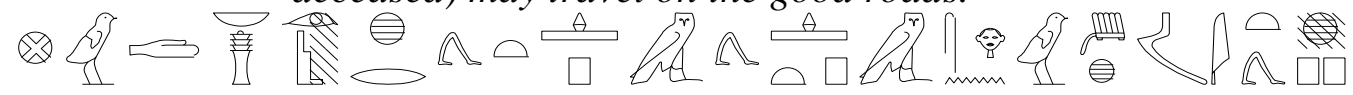

[h]ppt [9] im3hwww hr.sn m htp m htp hr Wsir nb-ddw

On which the revered ones travel on them in peace in peace to Osiris the lord of Busiris. 
The Estate-manager, sole companion, and lector priest, Isi, he says: I am one-who-says

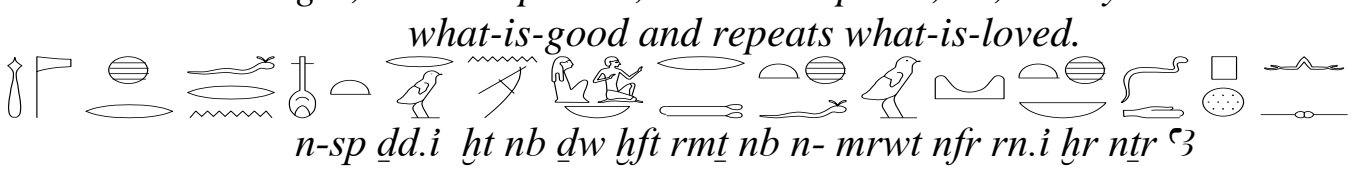

and I have never said anything evil about any person, in order that my name may be good at the Great God (= in His judgment),

3.3.5.

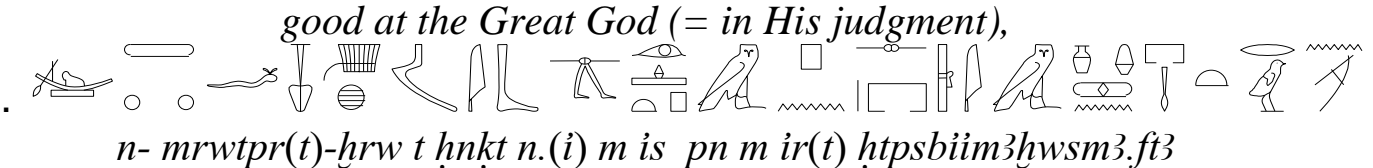

and in order that invocation-offerings of bread and beer may be presented in this tomb,

And by making offerings the revered-one may travel and land (= be interred).

3.3.6.

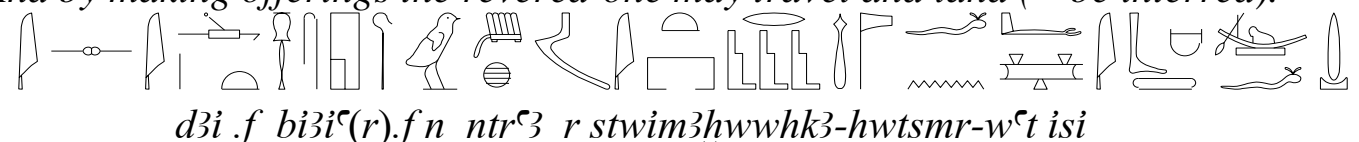
traverse the heaven and ascend to the Great God to the places of the revered ones: The Estate manager and sole companion Isi.

\section{Discussion}

The name of Isi wife and most of her representation are damaged, however in other texts of Isis tomb her name was $R^{e}$ $h m$ as on the north wall E. of the doorway [10]. $h k 3-h w t$ : At the vertical line before Isi representation, the title of Estate-manager appears. This title was given to the high rank officials in the royal court in the old kingdom [7]. smr-w'ty: At the vertical line before Isi representation, the title of the sole companion appears. This title was given to the most one close to the king. In addition, it indicates the privileged status to his owner for the king. Moreover, it was common in the texts of high rank officials of the old kingdom [11]. hry - hb: At the vertical line before Isi representation, the title of lector priest appears. He had not only to read the texts of the rituals, but also in some ceremonies he was a kind of prayer leader. In the early times, the members of the royal family obtained this rank and office [7]. The [III,1] line of hieroglyph was damaged after the shape of Anubis until the last two letters and the determinative of the word $i m y$-wt and after $\underline{d} s r$ and the first three letters of Krst ,it was completed as in parallel texts in other tombs in the same cemetery [9]. $\underline{d} s r$ : it is at the [III,1] line and written with two arms and hands holding a sword instead of its normal shape as $\Leftrightarrow$ an arm with hand holding nhbt scepter [12]. The top of the word htp at the [III,2] line pointed is not curved like the one existing at the [III,1] line. The sign $w 3 w t$ at the [III, 2] line is damaged, and it can be completed of parallel texts. At the begging of the [III, 3] line, the writing of the verb hppt is not usual, maybe the repeating of last letter indicates the Continuity. At the [III,3] line, the plural suffix $s n$ has not the sign of plural 1 । $!$ The writer at the [III,3] line use the sign $\wedge$ as a determinative to the infinitive $h t p$, also it is not common even in the parallel texts of the same cemet-

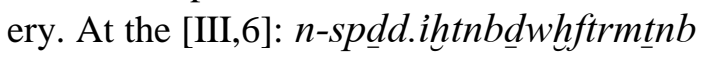
n- mrwtnfrrn.îhrntre3 I have never said anything evil about any person, in order that my name may be good at the Great God (in his judgment) [6]. This negative confession is similar to what is written in the pyramid's texts by the kings before the God Osiris in the nether world. In addition, this kind of texts was found within the old kingdom in the funeral texts of the common people together with high rank officials before it was written in pyramids texts. $r m \underline{t}$ was written without the plural sign at 
the [III,5] line. At the [III,6]: $\underline{d d}$.i: At the line, the suffixi does not exist, also at rn.i. n.(i): at the [III,7] line $n$.(i): the suffix $i$ does not exist, and at $t 3 \Longleftarrow$ it is written with two sand signs instead of three, and the sign of the ship was written briefly without any details at the end of this line together with the beginning of the next line. At the [III,8]: $i^{\top}(r)$ :it is written at VII line without the letter $r$.

\section{Conclusion}

This door lintel of Isibelongs to the end of the $5^{\text {th }}$ dynasty and the beginning of $6^{\text {th }}$ dynasty of the old kingdom. Although it bears no royal name, it has the style of the inscriptions that existed at the end of the old kingdom. This tomb lays in the northern part of the cemetery of Deir El- Gebrawi at Assiut, which belongs to the end of $5^{\text {th }}$ dynasty and the beginning of the $6^{\text {th }}$ dynasty while the southern part dated by the reign of PPi the $2^{\text {nd }}$ from the $6^{\text {th }}$ dynasty, as well by the name of the owner and his family. Moreover, by comparing it with the rest of tombs at the same site, and with another tomb from another area, there is a mastaba at Tell- Edfu, whose owner also called Isi, and he almost belongs to the same era (the beginning of the $6^{\text {th }}$ dynasty). Furthermore, he has the same titles as the owner of the Deir El-Gebrawi tomb, which confirms the dating of this tomb. Isi had many titles like the Hereditary prince, the HAty-a prince, the Chief Lector, Chief of pillared hall, the sem priest, the Ruler of Dw-f Nome and many other Tittles, and his tomb was carefully decorated by high skilled artists, who were often royal artistes. In addition, it refers to his high rank in the royal court.

\section{References}

[1]Ranke, H., (1935) Die Ägyptischen personennamen, Vol. I, J. J. Augustin, Glückstadt.
[2]De Garis Davies, N. (1902). Tomb Isi no.72, in: The rock tombs of Deir El Gabrawi, Vol. II, Gilbert and Rivington LTD. London

[3]De Garis Davies, N. (1902). Tomb no. 46, in: The rock tombs of Deir El Gabrawi, Vol. II, Gilbert and Rivington LTD. London

[4]Gauthier, H. (1975) Dictionnaire des nome geographiques contenus dans les texts Hieroglyphiques, OTTO Zeller Verlag, Osnabrück.

[5]Alliot, M. (1933). Rapport sur les fouilles dE Tell-Edfou, FIFAO, Tom.10 (2), pp: 8-45

[6]Sethe, K. (1933), Urkunden des Alten Reichs, Vol. 1, J.C. Hinirichs BU CH Handlung, Leipzig.

[7]Ward, W. (1982). Index of Egyptian administrative and religious titles of the middle kingdom, (no. 1114, p. 130), (no, 1299 - p. 151), (no, 140 - p. 1202), American Univ. of Beirut, Beirut.

[8]Leitz, C. (2002), Lexikon der Ägyptischen Götter und Götterbezeichnungen, Band I, Peters Louvian, Belgium.

[9]De Garis Davies, N. (1902). Tomb 12 of $\underline{d} 3 w$, in: The rock tombs of Deir El Gabrawi, Vol. II, Gilbert and Rivington LTD. London

[10] Jones, D. (2000) An Index of ancient Egyptian titles, epithets and phrases of the old kingdom, American Univ. of Beirut, Beirut.

[11] Sauneron, S., (1960). The priests of ancient Egypt, A. Borgoten Book, NY.

[12] Gardiner, A., (1994) Egyptian Grammar, Griffith Institute, Oxford. 